\title{
Transition Pathways for the Farmed Salmon Value Chain: Industry Perspectives and Sustainability Implications
}

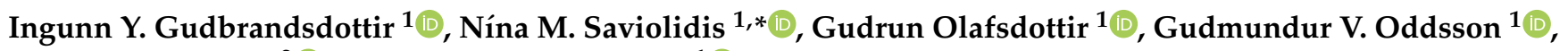 \\ Hlynur Stefansson ${ }^{2}$ (D) and Sigurdur G. Bogason ${ }^{1}$ (D) \\ 1 Faculty of Industrial Engineering, Mechanical Engineering and Computer Science, University of Iceland, \\ Dunhagi 5, 107 Reykjavik, Iceland; iyg1@hi.is (I.Y.G.); go@hi.is (G.O.); gvo@hi.is (G.V.O.); \\ sigboga@hi.is (S.G.B.) \\ 2 Department of Engineering, Reykjavik University, Menntavegur 1, 101 Reykjavik, Iceland; hlynur@ru.is \\ * Correspondence: nms@hi.is
}

Citation: Gudbrandsdottir, I.Y.; Saviolidis, N.M.; Olafsdottir, G.; Oddsson, G.V.; Stefansson, H.; Bogason, S.G. Transition Pathways for the Farmed Salmon Value Chain: Industry Perspectives and Sustainability Implications. Sustainability 2021, 13, 12106. https://doi.org/10.3390/ su132112106

Academic Editor: Giuseppe Antonio Di Vita

Received: 16 September 2021

Accepted: 29 October 2021

Published: 2 November 2021

Publisher's Note: MDPI stays neutral with regard to jurisdictional claims in published maps and institutional affiliations.

Copyright: (c) 2021 by the authors. Licensee MDPI, Basel, Switzerland. This article is an open access article distributed under the terms and conditions of the Creative Commons Attribution (CC BY) license (https:// creativecommons.org/licenses/by/ $4.0 /)$.

\begin{abstract}
Salmon is the most consumed farmed seafood in the EU and there is no indication that demand will abate. Yet salmon aquaculture's environmental impacts are significant, and its future is likely to be shaped by demands of increased but at the same time more sustainable production. This study developed an integrated theoretical framework based on the multi-level perspective (MLP) and a global value chain (GVC) governance framework and applied it to the global farmed salmon value chain. The objective was to provide insights on the most likely transition pathway towards sustainability based on industry and expert perspectives. The perceptions on challenges and drivers of change, were gathered through focus groups and in-depth interviews, and fitted to the integrated framework to facilitate the transition pathway analysis. Viewing the qualitative findings in the context of the MLP framework provided information about the current workings of the system, the drivers of change in the socio-technical landscape and niche-innovations and their potential to challenge or enhance the current system and thus indicated possible system transitions. To emphasize the role of industry actors in shaping the future of the salmon value chain, the analysis was strengthened using the GVC model which added information about power relations, signaling the ability of system actors to motivate or resist change. The findings indicate that, due to resistance in the regime and the fact that niche-innovations are not yet sufficiently developed, the farmed salmon value chain will continue to be predominated by traditional sea-based aquaculture but that there will be a gradual shift towards more diversity in terms of production methods in response to landscape pressures. The discussion addresses sustainability challenges and policy implications for the farmed salmon value chain and highlights the need for a food system perspective.
\end{abstract}

Keywords: transition theory; multi-level perspective; governance; global value chain framework; salmon aquaculture; sustainable food systems

\section{Introduction}

Sea-based salmon aquaculture is arguably one of the most advanced and most efficient animal-based food supply chains [1]. As an oily fish, salmon is a rich source of healthy fats and micronutrients necessary in the promotion of healthy diets [2]. However, there are several negative environmental impacts associated with sea-based salmon aquaculture such as sea lice [3], escapements, disease [4], eutrophication and algal blooms [5]. Salmon aquaculture also contributes to, and is impacted by, global environmental change and especially climate change through the provision of feed ingredients, production methods, distribution, and waste. Feed in particular is an important issue for the industry as it links fisheries, aquaculture, and terrestrial ecosystems [6]. Feed production is by far the largest contributor to the industry's environmental impact [7,8]. Transport is also responsible for a significant share of the carbon emissions of seafood supply chains, in particular transport of feed ingredients and air transport of products to distant markets $[9,10]$. 
The sustainability challenges of sea-based aquaculture are deeply rooted in the industry itself, the technology, the ways of working, interorganizational relationships and interdependencies, but also the wider societal structure, rules and regulations, institutions, and cultures. Therefore, their solution calls for extensive action, and a complete change from the current system to a transformed system might even be necessary. An understanding of the dynamics of such transitions, how they come about and evolve, drivers of change and structural inertia, may assist policy makers in their quest to bring about wide-ranging system transformations [11]. In general, sustainability transitions have been most-commonly defined as large scale transformations "deemed necessary to solve grand societal challenges" [12] (p. 600). Various transition theory frameworks have been developed and applied, but the multi-level perspective (MLP) is one of the more prominent ones [13] and has been applied to various integral socio-technical systems such as energy [14], mobility [15], and food [16].

The MLP is a particularly useful framework for aquaculture-a production system — since it emphasizes the embeddedness of technological innovations in social systems [17]. Innovative technologies have played an important role in aquaculture's expansion [18] and are often considered as integral to addressing sustainability concerns [19,20]. Despite the suitability of the MLP framework for aquaculture, very few studies have explored sustainability transitions in aquaculture through the framework. A recent systematic review of the use of the MLP in agri-food systems [13] identified only one study [17] with a focus on aquaculture. Bush and Marschke (2014) explored the contribution of the MLP framework to analyzing social dimensions of change for aquaculture in terms of resilience [17]. More recently, Mok and Gaziulusoy (2018) integrated theoretical insights from the MLP into strategic design considerations using Finnish aquaculture as a case study [21]. Hansen (2019) applied the MLP framework to examine the development of feed as part of a sustainability transition in Norwegian salmon aquaculture and concluded that economic factors have dominated in this transition which has not reached its full sustainability potential [22].

While the MLP framework includes policy as one dimension of the socio-technical regime, the role of power and politics in shaping transitions of socio-technical systems, mainly in the form of resistance to change has been under-theorized [23]. Furthermore, while the focus of transition studies has been on niche innovations, less attention has been paid to the forces maintaining the status quo within socio-technical systems [23]. The governance structure of a value chain provides information about interfirm relations and power dynamics within the chain [24]. A governance structure characterized by few dominant players and power asymmetries can indicate that incumbent actors are able to use their power to resist landscape pressures and steer future development away from fundamental system change [23]. A well-known framework for analyzing value chain governance is the global value chain (GVC) model [24], which has been used to study interfirm relations in various industries including food value chains [25-27]. In order to focus more on actors' motivation or resistance to change in socio-technical systems, this study incorporated elements of governance analysis based on the GVC model, into the MLP framework.

In this study, industry and expert perspectives in Iceland and Norway were analyzed using an integrated framework based on the MLP and GVC frameworks and the results used to explore potential pathways and challenges on the road towards a more sustainable farmed salmon value chain. The Norwegian aquaculture industry is the global leader in salmon farming and the most cost-efficient producers [28]. Other salmon producing countries are e.g., Chile, UK, Canada, Faroe Islands, and Iceland. The EU is the largest importer of salmon globally and absorbs around $60 \%$ of the total salmon export from Norway, mainly as fresh whole fish [29]. Many of the world's largest salmon producers are Norwegian enterprises and Iceland's salmon aquaculture industry is largely owned by Norwegian companies [30]. Fitting the farmed salmon value chain to the MLP framework provides information about the current workings of the system, the drivers of change in the socio-technical landscape and niche-innovations and their potential to challenge or enhance 
the current system and thus indicates possible system transitions. To emphasize the role of industry actors in shaping the future of the salmon value chain, the analysis is strengthened using the GVC model which adds information about power relations and hence indicates the ability of system actors to motivate or resist change. In addition, the sustainability contribution of niche innovations was estimated and thus their ability to challenge the status quo in the system. Based on the stakeholder perspectives, the governance analysis, and the sustainability contribution assessment, probable transition pathways towards sustainability for the farmed salmon value chain are suggested.

The study was part of a Horizon 2020 project called VALUMICS. The overarching aim of the VALUMICS project was to provide tools and approaches that inform decision-makers' evaluation of the impact of various policies with the ultimate aim of enhancing fairness, integrity and resilience in sustainable food value chains (FVCs). This article is structured as follows: Section 2 introduces the integrated framework by providing more detail on the MLP and the GVC approaches. Section 3 outlines the research method and analysis conducted for this study. The findings are then presented (Section 4), analyzed (Section 5) and finally discussed (Section 6). Section 7 provides the conclusion.

\section{Theoretical Background}

This section provides a more detailed overview of the MLP framework [23], including the different types of transition pathways as described by Geels and Schot (2007) [31], and the GVC governance framework [24,32] in the context of the salmon value chain and explains how an integrated perspective can increase understanding of sustainability transitions for salmon aquaculture.

\subsection{The Multi-Level Perspective on Sustainability Transitions}

The MLP posits that transitions take place through the interactions that occur in and between three main analytical levels: (a) landscape, (b) regime and (c) niche-innovations [31,33]. Transitions according to the MLP refer to changes in dominant regimes often resulting from landscape pressures and the emergence of niches which can be technological, social, or institutional [33]. Below each level of the MLP framework and the associated types of transition pathways are explained in more detail.

\subsubsection{Socio-Technical Landscape}

The socio-technical landscape refers to the external macro-level context of sociotechnical systems [31]. It consists of a series of heterogeneous elements (e.g., commodity prices, cultural values, broad political coalitions, environmental problems) and is the backdrop of agent interactions in the system, thus influencing the regime and niche innovations. While socio-technical landscapes do change over time the rate of change is slow and they are much more stable than regimes [34]. Landscape developments can either have a reinforcing relationship with the regime (e.g., urbanization and economic development leading to higher demand for salmon), or a disruptive one (e.g., increased focus on sustainability and animal welfare). When they occur, changes in the landscape that do not align with the current regime can put pressure on it, either resulting in "windows of opportunity" for niche-innovations to break through and radically influence or replace the dominant regime or lead to incremental changes to it [31]. Landscape pressures might be for example "demographic changes, macro-economic trends, political developments, wars and crises, deep cultural and societal values, and climate change" [13] (p. 2). The ongoing pandemic [35] constitutes an example of a crisis which can also act as a window of opportunity.

In the case of aquaculture, the socio-technical landscape is comprised of the food system as a whole. It is important to situate salmon aquaculture within the broader food system landscape as it affects and is affected by food system-level macrotrends [36]. The Food and Agriculture Organization (FAO) defines a food system as:

"The entire range of actors and their interlinked value-adding activities involved in the production, aggregation, processing, distribution, consumption and disposal of food 
products that originate from agriculture, forestry or fisheries, and parts of the broader economic, societal and natural environments in which they are embedded" [37] (p. 1)

In recent years, various landscape pressures in the socio-technical landscape of the farmed salmon value chain seem to have created the conditions for the emergence of a variety of innovations. One of the primary pressures is the tightening of regulations to address environmental challenges in connection to sea-based salmon aquaculture which has effectively limited expansion for major producers such as Norway [38] and Chile [39].

\subsubsection{Socio-Technical Regime}

The socio-technical regime is comprised of a set of interrelated, shared rules that coordinate the activities of actors in a socio-technical system [34]. These rules can be regulative (e.g., formal rules, laws, etc.), normative (e.g., values, norms), or cognitive (e.g., priorities, bodies of knowledge) and thus, contain both social and technical elements [11]. Socio-technical regimes serve important societal functions involving not only technologies but also user practices, markets, cultural meanings, public policies and regulations, business models, and infrastructure [40]. Due to the shared rules within an existing regime it tends to be stable. Nevertheless, it is maintained and improved in an incremental fashion by incumbent actors in response to landscape developments. Incumbent actors can be firms, users, scientists, policymakers, special interest groups, and civil society actors who interact with each other building networks and creating mutual dependencies [41].

Regime stability has been attributed to factors such as lock-ins and path dependence $[33,42]$ which lead to mostly incremental innovations rather than radical innovations [11]. Lock-ins can take various forms, i.e., (a) economic, due to vested interests, sunk investments in infrastructure and accumulated competences and scale advantages which often ensure low costs; (b) social, due to embedded beliefs, an alignment between social groups, and established user practices such as values and consumer preferences or beliefs which can be difficult to change; and (c) politics and power whereby incumbents will tend to resist change they perceive to go against their vested interests, and new entrants often have to contend with an uneven playing field and established policy networks which make it harder for innovations to break through [11]. While lock-ins and path dependence, seem to be out of direct control of individual incumbent actors, Geels (2014), has suggested that regime stability can be, at least in part, the outcome of active resistance by incumbent actors that have mutual dependencies and benefit from the status quo [23].

\subsubsection{Niche-Innovations}

Socio-technical innovations can emerge at all stages of the value chain and range from improvements in production technologies to changes in business models and value creation. While regimes generate incremental innovations, radical innovations are developed by small networks of actors, in niches, protected from 'normal' market selection in the regime. There they have room to develop, both the technology and the networks necessary to get it to the user. Initially, niche-innovations are unstable, show low technical performance and are often expensive. Therefore, they benefit from the protection of the niche until they are ready to compete with the dominant regime $[11,34]$. Few niche-innovations reach that level of performance or get the opportunity to break-through, but niches serve an important function as providers of space for learning processes [34] and sometimes niche-innovations are picked up by the regime and used to improve the dominant technology [31].

\subsubsection{Transition Pathways}

Geels and Schot (2007) developed a typology of transition pathways based on the timing and nature of multi-level interactions [31]. The status of niche innovation developments at the time of landscape pressure or internal struggles within the regime is important and has an impact on what kind of transition takes place. To be sufficiently developed to break through niche-innovations has to meet four conditions: (a) learning processes have stabilized in a dominant design, (b) the support network includes powerful actors, (c) price 
and performance have improved and there is indication of further improvements, and (d) the niche innovation is in use in market niches with a total market share of at least 5\% [31].

The nature of the relationship between the different levels also affects the type of transition. Landscape developments can either have a reinforcing relationship with the regime and thus support the status quo or a disruptive relationship which puts pressure on the current state. Similarly, niche innovations either have a competitive or symbiotic relationship with the regime and thus aim to replace it or enhance it [31]. Based on the timing and nature of multi-level interactions Geels and Schot (2007) defined four types of transition pathways in addition to the stable, reproductive regime: transformation, de-alignment and re-alignment, technological substitution, and reconfiguration (see Table 1) [31]. In addition, they proposed that a given transition may shift between pathways.

Table 1. Transition pathway typology (adapted from: [31]).

\begin{tabular}{|c|c|c|c|c|}
\hline $\begin{array}{l}\text { Transition } \\
\text { Pathways }\end{array}$ & $\begin{array}{l}\text { Landscape } \\
\text { Pressure }\end{array}$ & $\begin{array}{c}\text { Status of } \\
\text { Niche-Innovation(s) }\end{array}$ & $\begin{array}{l}\text { Nature of } \\
\text { Regime-Niche } \\
\text { Relationship }\end{array}$ & $\begin{array}{l}\text { Description of Type of } \\
\text { Transition Pathway }\end{array}$ \\
\hline Transformation & Moderate & $\begin{array}{l}\text { Not sufficiently } \\
\text { developed }\end{array}$ & Symbiotic & $\begin{array}{l}\text { Regime actors modify direction of } \\
\text { regime, but basic architecture } \\
\text { remains the same }\end{array}$ \\
\hline $\begin{array}{l}\text { Technological } \\
\text { substitution }\end{array}$ & High & $\begin{array}{l}\text { Sufficiently } \\
\text { developed }\end{array}$ & Competitive & $\begin{array}{c}\text { Niche-innovation(s) break through and } \\
\text { replace(s) regime }\end{array}$ \\
\hline Reconfiguration & Moderate & $\begin{array}{l}\text { Sufficiently } \\
\text { developed }\end{array}$ & Symbiotic & $\begin{array}{l}\text { Niche-innovations are adopted to solve } \\
\text { local problems and subsequently trigger } \\
\text { further adjustments eventually resulting } \\
\text { in a new regime with substantial } \\
\text { changes to regime's basic architecture }\end{array}$ \\
\hline $\begin{array}{l}\text { De-alignment and } \\
\text { re-alignment }\end{array}$ & High & $\begin{array}{l}\text { Not sufficiently } \\
\text { developed }\end{array}$ & Competitive & $\begin{array}{l}\text { Multiple niche innovations emerge and } \\
\text { co-exist until one becomes dominant }\end{array}$ \\
\hline
\end{tabular}

\subsection{The Global Value Chain (GVC) Governance Framework}

The GVC governance framework posits that increasing globalization of production and trade have led to significant structural changes in the governance of industries. The framework was developed to capture these structural governance shifts in sectors producing for global markets [24,32]. Specifically, Gereffi et al. (2005) defined five distinct value chain governance types, with different levels of coordination and power dynamics between chain actors (i.e., market based, modular, relational, captive and hierarchy) [24]. The GVC framework has proved useful in studying interfirm power relations and the role of lead actors, however, it has been criticized for not capturing the societal, political and policy contexts and interventions that occur in, and impact upon, intraregional European food value chains [27]. Further analysis in the VALUMICS project on the governance of food value chains through stakeholder interviews demonstrated that the characteristics of the salmon value chain governance, namely co-governance activities of three main categories of different actors: private firms, public actors and civil society fitted more with the extended GVC framework [32] and was more suitable for the global salmon value chain (Figure 1) [43]. 


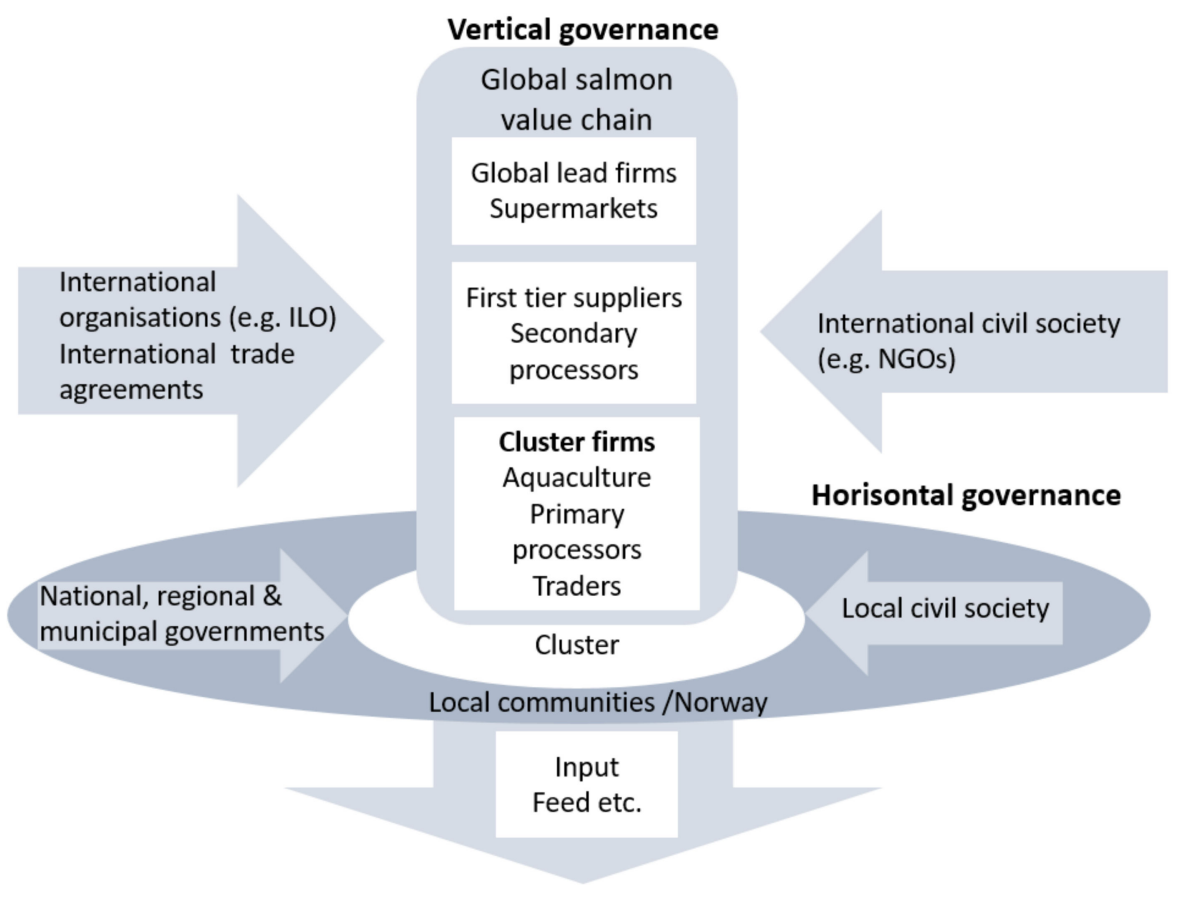

Figure 1. An extended GVC governance form suggested by Gereffi and Lee (2016) adapted to the governance structure of the Norwegian salmon aquaculture value chain, where GVC and cluster governance frameworks are combined (Source: [43]). (Note. ILO: International Labour Organization; NGOs: non-governmental organizations).

The structure of the salmon value chain starts with input suppliers of feed for the aquaculture production and extends through processing, wholesale, and retail/foodservice to the end consumer. On the supply side, the main actors are the aquaculture producers, dominated by large companies, some of which have integrated downwards in the chain by establishing processing facilities and trading companies in the EU to avoid tariffs and to ensure access to market. On the demand side, trading companies and wholesalers buy from integrated production companies or independent processors and sell to retail and foodservice who sell the end product to the consumer [43].

Power relations within the farmed salmon value chain and the impact of concentration and strategic coordination are important issues to consider in transitions. The interfirm relationships in the salmon value chain show signs of various governance forms depending on company size, level of vertical integration and product markets. The retail sector in France and the secondary processing sector in Poland dominate the salmon trade business, reflected in strong integration of these markets with the salmon export market in Norway [44]. The governance structure is best described as "hybrid" as networks of large integrated firms and their subsidiaries interact with other chain actors using a combination of arrangements. These range from a "market" structure with a low level of power asymmetries to "hierarchy" with high level of power asymmetries. The transactions between producers and primary processors selling commodity products (e.g., head-on-gutted) on the spot market to mostly wholesalers or secondary processors show characteristics of "market" governance. Product specifications are easily translated as they are based on industry standards, the complexity of transactions is low and the capabilities in the supply base are high. Therefore, the cost of switching business partners is low and the degree of explicit coordination and power asymmetry is low. However, even though there are no barriers to entry in trade activities, prevailing price volatility may discourage new entrants as it constrains the margins of secondary producers and traders [45].

Due to market conditions (demand far exceeding supply) producers are in a very favorable position which is further empowered by vertical integration which at times leads to a "hierarchy" form of governance. Although the chain is "producer driven" in that way, 
supermarkets are the lead firms with the most bargaining power. Independent secondary processors who carry out filleting, smoking and other value-added processing and are not a part of large integrated producing companies end up being 'stuck in the middle' in the value chain. They are positioned between two powerful actor groups, producers and retailers and need to negotiate both ways, sometimes by fixing price and volume in a long-term contract and then having to buy raw material on the spot market [46].

\subsection{An Integrated MLP and GVC Governance Framework}

The Norwegian aquaculture industry is the global leader in production and export of farmed salmon. It is characterized by consolidation at the farm level, with few large producers with international presence, extensive vertical integration, focus on technological innovations and close cooperation between industry, research, and government bodies $[43,46]$. The powerful position of aquaculture producers and the mutual dependencies of business actors, aiming to maximize their profit, and the Government, depending on businesses to provide jobs, tax payments and economic growth, highlights the importance of considering the role of power and resistance to change in transition studies [23]. This can be accomplished by adding an examination of the governance of the value chain to the transition pathway analysis. Specifically, governance structure provides information about power dynamics in the chain, who the lead actors are and the level of power asymmetries and thus the extent to which individual actors or a group of actors can resist change. Finally, adopting a governance framework to the study of transitions is important for two reasons: (a) it situates transitions in the real world and focuses research attention on the agents of change and their embeddedness in socio-economic systems, and (b) it incorporates political aspects as sustainability transitions often involve conflicting worldviews and objectives among different actors [47].

\section{Materials and Methods}

\subsection{Focus Groups and Interviews}

Data were collected in five in-depth interviews and two focus groups with three and four participants, respectively. The interviews included two Norwegian industry experts, three Norwegian aquaculture production company representatives and one high-level EU policy maker. The two focus groups in Iceland were comprised of three aquaculture production company representatives in the first group and one expert, and three aquaculture company representatives in the second group (Table 2).

Table 2. Descriptions of participants in the study's interviews and focus groups.

\begin{tabular}{|c|c|c|c|c|c|}
\hline Pseudonym & Organization & Role & Interview & $\begin{array}{l}\text { Focus } \\
\text { Group }\end{array}$ & $\begin{array}{c}\text { National } \\
\text { Context }\end{array}$ \\
\hline P1 & Funding agency & R\&D director & $\# 1$ & & $\mathrm{NO}$ \\
\hline P2 & $\begin{array}{l}\text { Research } \\
\text { institution }\end{array}$ & Expert & $\# 1$ & & $\mathrm{NO}$ \\
\hline P3 & Company & $\mathrm{CFO}$ & \#2 & & $\mathrm{NO}$ \\
\hline $\mathrm{P} 4$ & Public institution & Policy maker & \#3 & & EU \\
\hline P5 & Company & $\begin{array}{l}\text { Community } \\
\text { Relations }\end{array}$ & \#4 & & $\mathrm{NO}$ \\
\hline P6 & Company & CEO & \#5 & & $\mathrm{NO}$ \\
\hline P7/A1 & Company & $\mathrm{CFO}$ & & $\# 1$ & IS \\
\hline P8/A2 & Company & $\mathrm{CEO}$ & & $\# 1$ & IS \\
\hline $\mathrm{P9} / \mathrm{A} 3$ & Company & CEO & & $\# 1$ & IS \\
\hline P10/B1 & Public institution & Expert & & $\# 2$ & IS \\
\hline $\mathrm{P} 11 / \mathrm{B} 2$ & Company & $\begin{array}{c}\text { Project and } \\
\text { quality manager }\end{array}$ & & $\# 2$ & IS \\
\hline $\mathrm{P} 12 / \mathrm{B} 3$ & Company & CEO & & \#2 & IS \\
\hline P13/B4 & Company & CEO & & $\# 2$ & IS \\
\hline
\end{tabular}


Participants are only referred to by their pseudonyms to preserve their anonymity. Prior to the group discussions and interviews all participants received a short concept note with background information detailing the motivation of the research project. They also received a consent form which informed them of their rights and the ethical guidelines the study adhered to [48]. Participant selection was based on purposive sampling whereby industry representatives and experts were sought out based on their level of expertise. Participants were also asked to recommend other experts (snowball method) to ensure that key informants were included in the research.

\subsection{Procedures and Analysis}

The focus groups and semi-structured interviews were conducted online via the conferencing platform Zoom due to the COVID-19 pandemic and travelling restrictions. The design followed Daniels et al.'s (2019) recommendations for conducting online focus groups considering the particularities of the medium [49]. There were two researchers present at all the sessions. One researcher acted as the moderator steering the discussion towards relevant topics and ensuring all participants were afforded opportunities to voice their opinions. The other researcher acted as facilitator, taking notes, ensuring time limits were kept [50] and addressing any technical problems in case they came up [49]. The semi-structured interviews were also conducted using the same procedures to ensure consistency in the two approaches. A pilot session took place in April 2021 to test the materials and technical equipment. The focus groups and interviews were subsequently conducted in May-June 2021.

The question framework was semi-structured to ensure that all topics relevant to the analysis were included and to allow for more spontaneous discussion [51]. The aim of the focus groups was not to reach a consensus but rather to explore different perspectives [51]. The aim of the interviews was to gather in-depth information about the topics of interest from various stakeholders. Combining focus groups and interviews has been found to enhance data richness [52] and internal validity [53].

The sessions and interviews were all recorded in video form using Zoom's recording function and then transcribed. All sessions and interviews were conducted in English. The first two authors independently created mind maps of each session and interview, and these were then compared and discussed to ensure common understanding and to enhance internal validity (triangulating analysis) [53]. Data were subsequently coded by the first author using the analytical method of constant comparisons [54]. Standard country codes were also used to highlight cross-context analysis. The findings were then further analyzed using the integrated theoretical framework described in Section 2.

\subsection{Limitations}

Synchronous online focus groups and interviews do not differ substantially from conventional face-to face interactions in terms of the quality and richness of the data collected [55]. When certain elements are carefully considered and implemented at the design phase such as including a short introductory session to create a comfortable environment, making contingency plans for dropouts, and ensuring the facilitator can also provide technical support, all serve to mitigate the potential drawbacks of an online focus group $[49,56]$. Under normal circumstances online focus groups can present unique challenges most notably the challenge of participants not being entirely familiar with the use of online web conferencing services and bandwidth issues [56].

Although, we did make a contingency plan as recommended by [49], lack of familiarity with web conferencing services was not a challenge we encountered. An entire year of professional life adjusting to contagion measures due to the global pandemic has accelerated knowledge and familiarity with such services. In addition, neither technical nor bandwidth issues arose during the focus groups and interviews. Finally, although our participants were largely Norwegian and Icelandic industry actors, the issues discussed are common to most wealthy nations with aquaculture operations [57]. Norwegian companies 
are also the largest producers in the world, many with operations worldwide including in Iceland. The perceptions and views of powerful actors are important to gauge in the context of sustainability transitions.

\section{Findings}

This section presents main findings from the interviews and focus groups underpinning our analysis in Section 5.

\subsection{Socio-Technical Landscape}

Supply and demand and global environmental change were the main factors driving change in the farmed salmon value chain according to participants. The most discussed driver of change in the socio-technical landscape, consumer preferences, was related to increased demand for salmon. Participants stated that consumers increasingly call for more sustainable food production and are more concerned with issues such as animal welfare. Changing diets ranging from increased focus on health in general to more transformative change such as veganism were also mentioned as drivers of change that are currently affecting the industry.

"I'm positive for the industry, I think we'll be in a good place [by 2050], a sustainable place, because consumers - new generations - [ ... ] are very aware of sustainability, environmental impact and so on" (P8/A2).

Global environmental challenges, including climate change, were also mentioned as drivers of change in the current landscape, although on a longer timescale than the other drivers. Environmental challenges influence aquaculture production both directly (e.g., rising sea temperature) and indirectly through mitigative action. Various regulatory changes were discussed in the context of climate mitigation related to countries' NDCs (Nationally Determined Commitments) to the Paris agreement with some participants anticipating higher carbon taxes targeting for example transportation and other regulatory change in the near future.

"Of course, we see also the climate risk including future regulatory change. [This] is also a topic we discuss in every investment project. How are the regulations going to change, how do we have to invest today to adapt to future regulatory changes?" (P5)

Regional policies and strategies were also discussed as drivers of change at the national level, for example: the EU directive on non-financial disclosures, the EU Green Deal, the Sustainable Development Goals, and circular economy considerations (e.g., regulations on the use of by-products as feed). In the EU's Farm-to-Fork strategy, which is part of the Green Deal, the guidelines for sustainable aquaculture were also recently revised with an emphasis on increasing aquaculture production in the member states. The EU imports a large proportion of seafood and farming could increase the region's food security alongside other considerations such as health and nutrition, jobs, and livelihood objectives.

"Today, sustainability is still very important also in the context of the EU Green Deal and the Farm to Fork strategy: they recognize that farmed seafood is a good source of proteins and that it has a lower footprint and an important role to play in sustainable food systems." (P4)

Much of the discussion involved the increasing role of civil society (e.g., international, and local non-governmental organizations-NGOs) in sustainability awareness-raising and decision-making in the value chain. NGOs were discussed in terms of local communities' opposition to the industry, the effect on local-level decisions, and the difficulty of navigating the multiple and often differing objectives of different civil society organizations. However, the role of NGOs was also mentioned in the context of partnerships in certification schemes especially in relation to sustainable feed sources. Some participants also highlighted the importance of the private sector's presence in countries such as Brazil in terms of applying 
pressure to national authorities for halting deforestation in close collaboration with local and international NGOs such as WWF.

"We have to source soy from somewhere and we choose to source from Brazil because we are pushing them to become more sustainable by doing that, because we are in collaboration with NGOs to produce more sustainable feed. And if you leave the country completely then it's up to the local organizations there, and they don't have a lot of power" (P6).

Finally, the trade landscape was discussed in terms of macro-level trends that can affect the value chain, e.g., with regards to trade agreements and political tensions affecting trade.

"We have seen that political tensions between Russia, EU, NATO aren't becoming less common and there have been a few rounds where we have been excluded from China and also Russia-we are still excluded from Russia. And it doesn't seem like this trend is easing off." (P5)

The topics which emerged relating to the drivers in the socio-technical landscape are listed in Table 3.

Table 3. Elements of the socio-technical landscape mentioned by the participants.

\begin{tabular}{cc}
\hline Elements of the Socio-Technical Landscape & National Context \\
\hline consumer preferences) & EU, IS, NO \\
and demand (e.g., global crises, buyers' demand, & EU, IS, NO \\
Global environmental change (e.g., climate change, resource scarcity) & EU, IS, NO \\
International and regional policies and laws (e.g., Paris agreement, SDGs) & IS, NO \\
Civil society (e.g., environmental NGOs) & NO \\
\hline Trade landscape (e.g., trade agreements, market access, political tensions) &
\end{tabular}

\subsection{Socio-Technical Regime}

Market conditions were described by participants as very favorable with demand consistently exceeding supply resulting in generally favorable prices. The most discussed challenges were regulatory challenges, environmental challenges related to traditional production methods, and the negative public perception of the industry.

In Norway the regulatory challenges mostly mentioned related to the licensing system which hinders growth of traditional sea-based farming. Indeed, several participants mentioned that the policy environment, and specifically growth restrictions, are driving the industry to change their production methodologies because of economic concerns. In order to sustain growth, industry players need to find new ways of producing salmon. Policy initiatives such as the Norwegian developmental licenses further support these efforts by steering industry players towards other production methods.

"Obviously the most urgent driver is Norwegian policy and how the authorities are steering the development of our industry. One concrete example is of course developmental licenses. [ ... ] That's a clear driver for change. In order for us to be able to produce more salmon to grow as a company we needed to come up with [new] technologies" (P5).

When describing the current conditions in Iceland, where the regulatory system and the industry are still in development, most of the interviewees agreed that the system is overly complex, inefficient, time consuming and lacking predictability, resulting in detained growth.

"Licensing [in Iceland] is very time consuming, there is a lot of paperwork involved, often you have to do the same thing just a slightly different version for governmental institutions. So, it's not very effective and they don't have the people to work on everything they have to deliver" (P11/B2).

Many respondents mentioned the various environmental challenges of traditional sea-based farming, including mortality, diseases, problems related to lice, lice treatment 
and escapes. Repeatedly discussed in relation to environmental challenges were the carbon footprint of feed and transport which are responsible for a large share of the total carbon footprint of the industry.

"Salmon farming is like 80\% transportation: we are moving smolt, we are moving people, we are moving feed ... it's all on movement" (P9/ A3).

Icelandic participants specifically mentioned the challenges of operating traditional farming systems in their harsh environment, increasing the magnitude of problems related, to e.g., mortality and escapes. When discussing challenges of the industry today all participants in the study agreed that the negative public perception of salmon farming is a serious issue that needs to be addressed.

"Sometimes the critics of the industry are unfair, some are fair, and some do not base their criticism on facts. Discussion is healthy but it should be built on facts" (P12/B3).

All the topics which emerged relating to the current socio-technical regime are listed in Table 4.

Table 4. Topics relating to the socio-technical regime mentioned by the participants.

\begin{tabular}{lc}
\hline \multicolumn{1}{c}{ Aspects of Socio-Technical Regime } & National Context \\
\hline Strong market and profitability & EU, IS, NO \\
$\begin{array}{l}\text { National regulatory challenges } \\
\text { Growth restrictions (licenses) }\end{array}$ & IS, NO \\
$\begin{array}{l}\text { System deficiencies (e.g., complexity and lack of predictability, lack of } \\
\text { infrastructure, support, and direction) }\end{array}$ & IS \\
$\begin{array}{l}\text { Environmental challenges related to traditional sea-based production } \\
\text { systems (e.g., diseases, lice, mortality, escapes, carbon footprint, }\end{array}$ & \\
harsh environments). & EU, IS, NO \\
$\begin{array}{l}\text { Strong government-supported R\&D in Norway (e.g., development licenses) } \\
\text { which others benefit from. }\end{array}$ & \\
Rural development & IS, NO \\
Negative public image & IS, NO \\
\hline
\end{tabular}

Note. R\&D: research and development.

\subsection{Niches}

In terms of technological developments, participants both mentioned advances related to the traditional methods of producing and distributing salmon (e.g., digitalization and improved biology) and more disruptive developments that could potentially have a more transformative effect on the current socio-technical regime (e.g., land-based, and offshore salmon farming). Participants mentioned several developments aimed at improving traditional salmon production and distribution methods. Very prominent were solutions aimed at reducing the carbon footprint of feed and transport, particularly the development of new raw materials for feed, bringing feed production closer to production, and the combination of improved freezing/thawing technologies and more sustainable modes of transport.

"Feed is by far the largest GHG contributor to our product [ . . ] 80\% of the climate emissions related to salmon aquaculture is feed and transport of feed. We need to make sure that the production and transport of these ingredients are [improved] going forward" (P5).

Technological improvements of open net pen farming were frequently mentioned, including the digital transformation of fish monitoring, and feeding technologies. Many interviewees also mentioned innovations aimed at battling the biggest biological challenges in open net pen farming, namely diseases, lice, and mortality. These include the development of better vaccines and genetic innovation. Furthermore, the progression towards larger smolts aimed at better utilizing licenses and diminishing the likelihood of diseases was also a recurrent theme in the interviews. 
"For sea cage aquaculture: it will develop but I foresee that the size of smolts will be larger so the time in the sea will be shorter and that solves problems with escapes and sea lice. So, this will be one of the system transformations and [will] make it more sustainable" (P10/B1).

In addition, also mentioned as potential updates to the current regime were different advancements related to marketing and product development such as more focus on value added products, branding, and convenience food resulting in more product diversification.

"So going from whole fillets of smoked salmon to $200 \mathrm{gr}$ packs to $100 \mathrm{gr}$ packs to $50 \mathrm{~g}$ I think is a development [ ... ] Salmon is running 12 years behind chicken and cod is running 5 years behind salmon in terms of product development. Innovation on the product side is a key driver" (P3).

As a potential improvement of the current farming system, elements of circular economy such as whole fish utilization and the production of biogas from sludge were mentioned by several participants.

"If we are serious about increasing [circularity] then we need to make these discussions happen and we need to start asking the consumer these questions: what are [you] willing to compromise in order to have more sustainable food choices?" (P6).

Land based salmon farming using recirculating aquaculture systems (RAS) was the most frequently mentioned topic by participants. Other frequently mentioned new technologies were offshore farming, closed or semi-closed farming systems, aquaponics, and organic aquaculture.

"In 2050 we will have land-based salmon farming as a big segment living side by side with the traditional farms in the fjords ... I think there is plenty of room for many technologies and they will live side by side" (P3).

All the topics which emerged relating to niche developments are listed in Table 5.

Table 5. Niche innovations mentioned by the participants.

\begin{tabular}{cc}
\hline Type of Niche Innovation & National Context \\
\hline Socio-technical improvements to traditional farming distribution & \\
systems (symbiotic) & \\
Larger smolt & IS, NO \\
Improved biology (e.g., vaccine, genetic innovation) & EU, IS, NO \\
Circular economy (e.g., full utilization, sludge management, biogas) & IS, NO \\
Digitalization (e.g., monitoring, feeding technologies) & EU, NO \\
Sustainable feed (e.g., alternative ingredients, local feed production) & EU, IS, NO \\
Sustainable transport (e.g., transport and freezing/thawing innovation) & IS, NO \\
Diversified products (e.g., more value added, branding, convenience food). & EU, IS, NO \\
New farming systems (competitive) & EU, IS, NO \\
Land-based farming & EU, IS, NO \\
Offshore farming & NO \\
Closed/semi-closed sea-based farming & Aquaponics \\
Organic aquaculture & EU, IS, NO \\
\hline
\end{tabular}

\section{Summary Findings and Analysis}

This section presents our summary findings through the integrated framework (Section 5.1), an evaluation of the sustainability potential of niche-innovations emerging from the findings (Section 5.2) and, the delineation of likely transition pathways for the industry (Section 5.3). 


\subsection{The Farmed Salmon Value Chain in the Context of the Integrated MLP and GVC Governance Framework}

Figure 2 summarizes our findings through the integrated framework developed in this study.

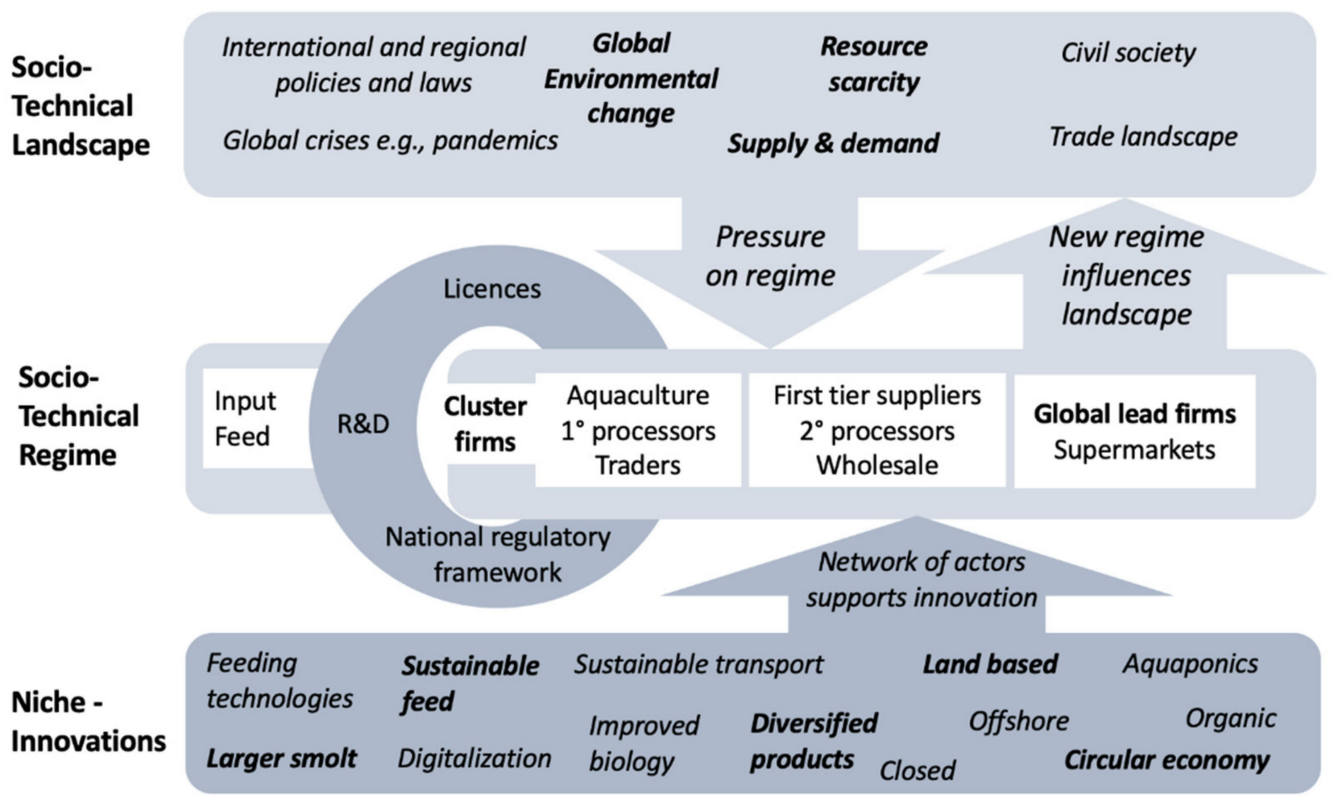

Figure 2. Summary findings through the integrated framework (authors' own conceptualization based on existing frameworks [31,32,43]).

The stakeholder interviews provide information about the farmed salmon value chain in terms of the three levels of the MLP framework. They highlight the most prominent landscape developments and pressures, the current state of the value chain in terms of shared regulative, normative, and cognitive rules, and the niche-innovations currently in development. To strengthen the analysis and the resulting estimation of the most likely transition pathway towards increased sustainability, a governance perspective was added using the GVC governance framework and was transposed to represent the sociotechnical regime (see Figure 2). Based on the governance analysis of the farmed salmon value chain presented in Olafsdottir et al., 2019, the interactions between the different levels and specifically the reactions of the current regime to landscape pressures and looming niche-innovation breakthroughs, are placed in a value chain governance perspective [43].

As discussed in Section 2.2. what characterizes governance in the farmed salmon value chain are horizontal collaboration and vertical integration, including relations through networks, third-party assessment, and certification schemes on top of the traditional model of state-only regulations (licenses and environmental impact assessments) representing a hybrid governance form in aquaculture [58]. This form of governance further entails that the global salmon value chain is influenced by international organizations and trade agreements, international civil society, and industry initiatives, which on the other hand are motivated by societal pressures from non-governmental organizations e.g., through sustainability standard settings and auditing (e.g., Aquaculture Stewardship Council).

In terms of innovation and industrial development, the success of salmon farming in Norway is based on close cooperation between industry actors, governmental bodies and research institutes which contribute to a strong cluster [46]. The governance structure of the farmed salmon value chain points to power asymmetries. There are powerful value chain actors and networks of actors with vested economic interests in sustaining the current regime. Furthermore, the hybrid form of governance indicates flexibility and ability to adjust. Specifically, large integrated producers are in a powerful position in the chain, and they are heavily invested in the traditional form of sea-based salmon farming. Their hybrid 
governance structure also makes it easier for them to adjust to landscape pressures through incremental adjustments (symbiotic niches) to the prevalent technology of sea-based cages. Incumbent actors are driven by profits and therefore their resistance could ease if the relative profitability of traditional farming compared to the niche farming systems changes due to for example increased mitigation costs. In the next section we critically assess proposed solutions (niche innovations) based on their potential contributions to a more sustainable farmed salmon value chain. This is important because it underpins participants' perceptions on the potential of niche breakthroughs and resulting pathways.

\subsection{Sustainability Contributions of Niche-Innovations in Salmon Aquaculture}

There was common agreement among participants that salmon aquaculture is set to expand in the future both due to increasing demand for salmon but also because national and regional-level governments project and plan for its increase (e.g., $[59,60]$ ). This perspective is also echoed in high-level policy reports [61,62] and recent academic literature [2,63]. As such, the discussions centered around how to achieve growth in a sustainable manner with the range of niche innovations emerging from these discussions. Hansen (2019) highlighted, that an analysis of transition pathways without an assessment of overall contribution to sustainability outcomes provides an incomplete picture of the underlying challenges that need to be addressed [22]. Therefore, a critical evaluation of niche innovations in terms of their sustainability contributions was necessary, providing a more comprehensive assessment of the sustainability transition of the farmed salmon value chain and emphasizing the limitations of the mentioned niche-innovations in terms of contributions to sustainability challenges. For a niche-innovation to be able to compete with the current regime it needs to solve more of the regime's problems than it adds to it.

Numerous sustainability challenges related to traditional sea-based salmon farming have been identified both in the literature [64-66] and in this study. These mainly relate to environmental sustainability, but also economic viability and animal welfare. Table 6 summarizes the contributions of the niche innovations mentioned in the interviews with regard to various known sustainability challenges in the farmed salmon value chain, based on selected literature. The niche-innovations are shown to have either a positive effect $(+)$ on a given challenge compared to traditional sea-based farming, a negative effect $(-)$, or no known effect (0). The analysis is not exhaustive, in part due to a general lack of comprehensive assessments in the literature for many of the niches. Nonetheless, it provides an overview of the major sustainability challenges according to the literature and an initial explorative evaluation of the extent to which they are addressed by the selected niche-innovations.

As can be seen from Table 6, many of the niches solve delimited challenges, have little or no effect on others and might add to some. Their design and objectives are naturally in alignment with the focus of regulatory bodies and other forces that shape the current regime. In terms of the salmon value chain the focus has been on local environmental challenges related to aquaculture production and less on global sustainability challenges such as carbon emissions and therefore many of the niches are geared towards solving those challenges. Other niches center on global sustainability challenges, but none are capable of addressing both. In addition, almost none of the niche-innovation developments have reached a level of economic feasibility. 
Table 6. Contributions of niche innovations towards selected sustainability challenges in the farmed salmon value chain.

\begin{tabular}{|c|c|c|c|c|c|c|c|c|c|c|c|c|c|c|}
\hline \multirow[b]{3}{*}{$\begin{array}{l}\text { Niche- } \\
\text { Regime } \\
\text { Relationship }\end{array}$} & \multirow[b]{3}{*}{ Niche Innovations } & \multicolumn{12}{|c|}{ Sustainability Challenges } & \multirow[b]{3}{*}{$\begin{array}{c}\text { Select } \\
\text { Academic } \\
\text { Literature }\end{array}$} \\
\hline & & \multicolumn{9}{|c|}{ Environmental } & Econ. & \multicolumn{2}{|c|}{ Social } & \\
\hline & & : & 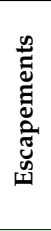 & 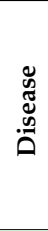 & 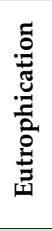 & 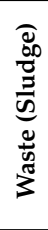 & 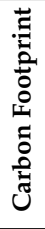 & 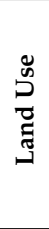 & 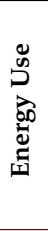 & 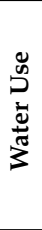 & 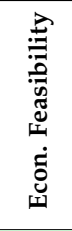 & 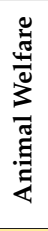 & 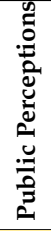 & \\
\hline Symbiotic & $\begin{array}{l}\text { Larger smolt } \\
\text { Improved biology } \\
\text { Circular economy } \\
\text { Digitalization } \\
\text { Sustainable feed } \\
\text { Sustainable transport } \\
\text { Diversified products }\end{array}$ & $\begin{array}{l}+ \\
+ \\
0 \\
+ \\
0 \\
0 \\
0\end{array}$ & $\begin{array}{l}+ \\
+ \\
+ \\
0 \\
+ \\
0 \\
0 \\
0 \\
0\end{array}$ & $\begin{array}{l}+ \\
+ \\
0 \\
+ \\
0 \\
0 \\
0\end{array}$ & $\begin{array}{l}+ \\
0 \\
0 \\
+ \\
0 \\
0 \\
0\end{array}$ & $\begin{array}{l}- \\
0 \\
+ \\
0 \\
0 \\
0 \\
0 \\
0\end{array}$ & $\begin{array}{l}- \\
0 \\
+ \\
0 \\
+ \\
+ \\
+\end{array}$ & $\begin{array}{l}- \\
0 \\
0 \\
0 \\
0 \\
0 \\
0\end{array}$ & $\begin{array}{l}- \\
0 \\
+ \\
0 \\
0 \\
0 \\
0 \\
0\end{array}$ & $\begin{array}{l}- \\
0 \\
0 \\
0 \\
0 \\
0 \\
0 \\
\end{array}$ & $\begin{array}{l}+ \\
0 \\
0 \\
- \\
- \\
0 \\
0\end{array}$ & $\begin{array}{l}0 \\
+ \\
0 \\
+ \\
0 \\
0 \\
0\end{array}$ & $\begin{array}{l}0 \\
0 \\
+ \\
0 \\
+ \\
+ \\
0\end{array}$ & $\begin{array}{l}{[67]} \\
{[67,68]} \\
{[69]} \\
{[70,71]} \\
{[70]} \\
{[9]} \\
{[72]}\end{array}$ \\
\hline Competitive & $\begin{array}{l}\text { Landbased farming } \\
\text { Offshore farming } \\
\text { Closed/semi-closed } \\
\text { Aquaponics } \\
\text { Organic Aquaculture }\end{array}$ & $\begin{array}{l}+ \\
+ \\
+ \\
0 \\
-\end{array}$ & $\begin{array}{l}+ \\
0 \\
+ \\
0 \\
0 \\
0\end{array}$ & $\begin{array}{l}+ \\
+ \\
+ \\
0 \\
-\end{array}$ & $\begin{array}{l}+ \\
+ \\
+ \\
+ \\
0 \\
\end{array}$ & $\begin{array}{l}- \\
0 \\
0 \\
+ \\
0\end{array}$ & $\begin{array}{l}- \\
- \\
0 \\
+ \\
0 \\
\end{array}$ & $\begin{array}{l}- \\
0 \\
0 \\
- \\
0\end{array}$ & $\begin{array}{l}- \\
- \\
- \\
+ \\
0\end{array}$ & $\begin{array}{l}- \\
0 \\
0 \\
+ \\
0\end{array}$ & $\begin{array}{l}- \\
- \\
- \\
- \\
-\end{array}$ & $\begin{array}{l}- \\
+ \\
0 \\
0 \\
+ \\
\end{array}$ & $\begin{array}{l}+ \\
+ \\
+ \\
+ \\
+\end{array}$ & $\begin{array}{l}{[67,70,73]} \\
{[19,20,67,70]} \\
{[67,73]} \\
{[20,64]} \\
{[74-76]}\end{array}$ \\
\hline
\end{tabular}

Note. (+): positive effect; (-): negative effect; (0): no effect or N/A.

A fully contained farming system reduces biodiversity impacts to zero (no escapes) but siting needs to take very careful consideration of land use issues, clean energy provision, and fish welfare concerns, and at the same time be able to compete with traditional seabased systems on economic terms [70,77]. Similarly, closed/semi-closed and offshore farming systems are intended to lessen biodiversity impacts [67] but even with perfect siting conditions met, these farming systems do not address sustainable feed provision, the farmed salmon value chain's main source of carbon emissions [22]. Full life cycle analyses of farming systems are necessary in order to include otherwise neglected sources of carbon such as embedded emissions from construction.

Symbiotic niches focused on environmental challenges related to aquaculture production include digitalization and biological improvements (i.e., triploid fish). The digital transformation of aquaculture using tools such as computer vision and environmental monitoring leads to more sustainability through, e.g., early detection of problems regarding animal health and welfare [71], improved feeding techniques reducing water pollution and optimized feed use [78]. An example of biological improvements aimed at reducing environmental impacts are triploid fish which are sterile and therefore potentially reduce the negative impact of escapes [68].

There are symbiotic niche innovations which many incumbent companies could implement right now to tackle a sizable part of their carbon emissions including reducing emissions from transportation throughout the supply chain [10]. Reducing transport emissions relates to optimizing logistics and product development. In this regard, freezing technologies and maritime transport instead of air transport constitute opportunities for emissions reductions especially if customers and consumers can be convinced that quality is not compromised. Less reliance on the aviation sector may also constitute a proactive strategy for companies since the aviation sector is facing increased pressure to decarbonize [79] and exhibited limited resilience to sudden shocks such as the pandemic [80].

In addition, value-added activities constitute a viable avenue for improved resource utilization and reduced carbon emissions for the farmed salmon value chain but may be constrained by various factors. Approximately $80-90 \%$ of Norway's production volume is exported as marginally processed, fresh products to EU countries and by airfreight to the Asian markets $[81,82]$. Increasing processing in Norway and exporting more value-added products would have benefits for both the Norwegian industry and society and globally by reducing the carbon footprint of the industry as around $50 \%$ of what is currently transported is by-products [72]. There are several challenges standing in the way of increased processing in Norway including high labor costs compared to the EU, lower margin of processors than producers [83], and higher tariffs on value-added products [84]. 
Some of the declared benefits of a circular economy are waste and carbon emission reduction. However, circular economy considerations are not fully developed despite the rhetoric pervading the discourse [84]. It is unclear what the concept of a circular economy really entails, and different stakeholders do not always have the same understandings as previous research has also shown [85]. As participants also pointed out, various circular solutions to sustainable feed have not been adequately explored and public debate has been minimal. Consumer reticence, public opposition and regulatory frameworks may be significant barriers in circular economy solutions such as the use of animal by-products in feed for aquaculture. Livestock by-products in feed have also been found to significantly raise the environmental impacts of farmed salmon $[7,86]$. Aside from that, it is important to consider whether creating mutual dependencies with the livestock sector constitutes a viable long-term solution for aquaculture and pollution prevention in general. Careful consideration needs to be paid also to fish health and nutritional quality when changes in feed composition are pursed [87].

In the next section, probable transition pathways of the salmon value chain are proposed based on the stakeholders' views on the landscape pressures on the current regime, the governance analysis of the regime and the proposed niche innovations and their contribution to addressing sustainability challenges.

\subsection{Probable Transition Pathways of the Farmed Salmon Value Chain towards More Sustainability}

Following Geels and Schot (2007)'s typology [31] described in Section 2.1.4 and Table 1, our findings, based on the mapping of stakeholder perspectives to the MLP framework, governance analysis and the sustainability contributions of niche-innovations, suggest that a transformation pathway is the most likely direction that the industry will take in the next decades. Although, landscape pressure, specifically related to global environmental change and changing consumer preferences, seems to be reasonably high and on the rise, it continues to be offset by the resistance to change by powerful actors in the regime and their ability to adapt and align their production network enough to alleviate some of the pressure. Furthermore, competitive niche-innovations such as land based, and offshore farming systems do not seem to be sufficiently developed to compete with the highly efficient traditional sea-based farming systems. Therefore, a gradual transformation towards more sustainability within the current regime with, mainly, regime driven innovations and refinements is the most likely future.

There is, however, a small potential for a technological substitution pathway depending mostly on how aggressive policy interventions in response to environmental challenges will be and the developmental progress of alternative production systems, especially in terms of economic viability. If the landscape pressure becomes too heavy for the regime actors to withstand and align to, possibly resulting in disruptive policy interventions such as a total ban on sea-based aquaculture, the course towards sustainability could be different. Indeed, such a transition might be underway in Canada, where the Government has set in motion a plan to completely transition from open-net pen farming in coastal British Columbia (BC) by 2025. The aim is to protect and rebuild the wild fish stocks in the area and at the same time position $\mathrm{BC}$ as a global leader in innovative and sustainable aquaculture [88]. If the development of niche-innovations such as land-based farming is sufficient when such a disruptive policy intervention takes place, a technological substitution would probably take place. Otherwise, a de-alignment and re-alignment transition would take place eventually resulting in a new regime.

It should be noted that this study was largely based on incumbents who have a clear stake in the industry's current direction. Nonetheless, the perceptions of industry experts and that of a CEO of a company heavily invested in land-based activities did not significantly diverge from the perceptions of the incumbents, indicating that this pathway description is not entirely biased. It is also difficult to ascertain whether these perspectives represent resistance to change and cognitive bias or legitimate assessment of the potential of different innovations to transform their industry [89]. 


\section{Discussion}

As this study has shown, numerous often interrelated factors can influence the direction of an industry. This ranges from drivers at the landscape level to various regime developments, and not least the maturity and potential breakthroughs of niche-innovations. Crucially, when viewed in the context of the integrated MLP and GVC framework, the governance structure of the farmed salmon value chain indicates that incumbent actors in the chain are in a strong position to resist change to a new regime, using power to withstand landscape pressures and flexibility to adapt when needed. Most participants agreed that sea-based aquaculture would predominate in the future although diversity in terms of farming systems would increase. This transition pathway of gradual change is mainly the result of the interplay of the different factors summarized in Figure 2 and the preliminary analysis of niches' state of development in Table 6 . In what follows, we briefly discuss some of the governance implications of these findings and how a food system approach can be useful in this context.

Political decisions can heavily influence salmon aquaculture by regulating the location of farm sites and slaughter plants and their social impacts on communities. Limited availability of new licenses for salmon farming in Norway motivates Norwegian companies to operate and expand salmon production in other salmon producing countries (e.g., Chile, Scotland, US, Canada, and Iceland) to ensure continued growth and stable supplies of Atlantic salmon to markets. However, many salmon producing wealthy nations (including Iceland and Norway) are facing similar socio-ecological challenges which have placed limits to salmon aquaculture expansion [57].

The fact that aquaculture is a biological process carried out in an open environment and that there are still uncertainties regarding its environmental impact, poses challenges for both industry actors and governmental agencies. These challenges have been described as a wicked problem [90]. Fish farmers continually deal with environmental uncertainties in their operations and they, as well as policy makers, face steady pressure from society and media to quickly adapt to rapid improvements in knowledge regarding environmental externalities and the associated technological advancements. These challenges make the salmon value chain both hard to manage and govern and call for a flexible and adaptive approach to governance [90,91]. Therefore, hybrid forms of governance characterized by the active involvement of non-state and state actors [92] will likely continue to play an important role in the industry's ongoing pursuit of social legitimacy and for solving grand sustainability challenges where collaboration and coordination of different actors is necessary.

Collaboration and coordination point to the need of providing formal procedures for genuine engagement of stakeholders in deliberation, decision-making, and management of conflicts in connection to aquaculture sites and impacts are of crucial importance to the industry's social license to operate [58]. Iceland, as an example, could benefit from the implementation of comprehensive marine spatial planning processes [57] which would ensure that legitimate concerns of local communities and civil society groups are addressed through formal avenues. It is also important to have a robust governance system which seeks to prevent conflict of interest in the regulatory and administrative system strengthening accountability and thus public trust and acceptance [93].

The need for accountability and transparency has been partly addressed through the creation of multistakeholder certification schemes which are a form of self-regulation by the private sector serving a value and trust enhancing purpose in the market [94,95]. Multistakeholder certification schemes, such as the Aquaculture Stewardship Council, have emerged as a way of meeting normative demands of various stakeholders regarding the sustainability performance of companies. The hierarchical form of governance in salmon aquaculture [43] makes it easier for firms to adopt certifications as vertical integration facilitates the implementation of standards [96]. This, however, also means that smallholders and companies in the global south with fewer capabilities to implement standards may be excluded from markets [93] leading ultimately also to slow uptake of the standards 
globally. A relatively narrow focus on sustainability especially in terms of long-term biophysical impacts [97] is also a major limitation.

National regulations constitute an influential driver of change as can be seen by the impact of the licensing system in Norway on the industry [98]. As Hersoug (2015) has shown by emphasizing lice as the single most important performance indicator, the Norwegian licensing system effectively restricted environmental sustainability considerations to the narrow focus of biological sustainability [98]. Although protection of local ecosystems and wild species is important, the question arises whether stakeholders' sustainability considerations should be broadened to include the entire value chain and its impact from a food system perspective with a view towards balancing local and global concerns [99]. Broadening actors' perspectives and reframing challenges in a food system perspective which considers the whole value chain and its role in the wider system is important for transitioning the industry towards more sustainability [100]. As the European Environment Agency stated in a recent report: "sustainability in food requires a policy framework that embraces a food system approach, and that allows a shared understanding of the food system to be built" [6] (p. 5). Achieving this shared understanding among the different stakeholders of the farmed aquaculture value chain may be a viable way forward in ameliorating conflicts as well as an important consideration for a sustainability transition.

From a food system perspective, salmon constitutes a healthy source of animal protein with relatively lower environmental impact compared to other animal protein sources [8]. However, for salmon aquaculture to grow sustainably, livestock pressures on the environment would have to be achieved concurrently. As previous research has shown [22] and participants confirmed, one of the major sustainability challenges for the farmed salmon value chain is the provision of sustainable feed. No niche so far can resolve the reliance of farmed salmon on plant and, to a lesser extent, marine-based proteins and alternative feed sources come with their own drawbacks and possible unintended consequences [101]. In fact, our analysis showed that no single niche innovation adequately addresses the various sustainability challenges of the farmed salmon value chain. In addition, most of the policy-making focus has been on the production-side, thus allowing opportunities to address large sustainability challenges along the entire value chain to remain unexploited.

Recent scientific assessments underscore the importance of reducing meat consumption from a health and sustainability perspective $[63,102]$ and both regional and national policies have begun to incorporate this goal in their dietary recommendations and policy frameworks $[103,104]$. Although seafood has been afforded less consideration in the transition to more sustainable food systems, it has an important role to play due to its nutritional profile and its relatively lower environmental impact compared to livestock [2]. Seafood's nutritional significance is due to the provision of protein, healthy fats, and essential nutrients [105]. Aquaculture, in particular, has been singled out as a sector that will need to expand production to meet future food demand in part due to the stagnating state of capture fisheries [106]. The production efficiency, nutritional contribution and comparatively lower environmental impact of farmed salmon are reasons to consider it in debates about the role of seafood in sustainable food systems.

The lack of integration of fish in food policies in general [105] and the relative dearth of studies assessing the role of seafood-both wild and farmed-in sustainable food systems constitute important future research directions [99]. Negative public perceptions of the industry at both the local (community) and international level emerged as one of the major challenges for conventional sea-based aquaculture underpinning previous research [107]. Emphasizing the industry's role in providing healthy and nutritious products with a relatively lower environmental footprint compared to other animal protein production may represent a useful strategy for improving the industry's public image.

\section{Conclusions}

This study elicited the perspectives of industry representatives and experts to explore and evaluate future directions towards a more sustainable farmed salmon value chain. 
It contributed to research on socio-technical transitions through the integration of the MLP framework on sociotechnical transitions and the GVC framework on governance in value chains. The addition of governance analysis to transition studies is useful for emphasizing the role of different actors in contributing to regime resistance [23] and thus the development of transition pathways. The assessment of sustainability contributions of niche-innovations further strengthened the analysis by indicating their ability to challenge the current regime. Applying these frameworks to the farmed salmon value chain provided insights into the drivers and barriers to the transition towards sustainability and how policymakers, managers and other actors can promote and support a sustainability transition.

There was broad consensus amongst the interviewed stakeholders on the most likely pathway i.e., not a complete regime shift but rather a continuance of the dominant regime with a gradual shift towards more diversity in production methods. This finding is supported by the governance analysis, which highlights the power of regime actors to resist change, and the analysis of the sustainability contributions, which indicates that they do not address some of the major sustainability challenges in the chain (e.g., sustainability of feed and transport). The result of the sustainability contribution analysis also reflects the industry's focus on local environmental challenges rather than global sustainability challenges such as the carbon footprint of the extended value chain. In order to find a path towards more sustainability in the farmed salmon value chain a broader food system perspective is needed.

Author Contributions: Conceptualization, I.Y.G., N.M.S., G.O. and S.G.B.; methodology, I.Y.G., N.M.S. and G.O.; formal analysis, I.Y.G. and N.M.S.; investigation, I.Y.G. and N.M.S.; data curation, I.Y.G., N.M.S. and G.O.; writing—original draft preparation, I.Y.G., N.M.S. and G.O.; writing—review and editing, I.Y.G., N.M.S., G.O., G.V.O., H.S. and S.G.B.; visualization, I.Y.G. and G.O.; supervision, G.O., G.V.O., H.S., S.G.B.; project administration, G.O. and S.G.B.; funding acquisition, S.G.B. All authors have read and agreed to the published version of the manuscript.

Funding: The VALUMICS project "Understanding Food Value Chain and Network Dynamics" has received funding from the European Union's Horizon 2020 Research and Innovation Programme under Grant Agreement No 727243.

Institutional Review Board Statement: Ethical review and approval were waived for this study because the study did not involve the processing of personal data. The study adhered to ethical standards for the VALUMICS project in accordance with EU Horizon 2020 regulations on data management concerning ethical and societal aspects (Directive (EU) 2016/680).

Informed Consent Statement: Written informed consent was obtained from all subjects involved in the study.

Conflicts of Interest: The authors declare no conflict of interest. The funders had no role in the design of the study; in the collection, analyses, or interpretation of data; in the writing of the manuscript, or in the decision to publish the results.

\section{References}

1. Asche, F.; Cojocaru, A.L.; Roth, B. The development of large-scale aquaculture production: A comparison of the supply chains for chicken and salmon. Aquaculture 2018, 493, 446-455. [CrossRef]

2. Troell, M.; Jonell, M.; Crona, B. Scoping Report: The Role of Seafood in Sustainable and Healthy Diets: The EAT-Lancet Commission Report through a Blue Lens; Stockholm Resilience Centre: Stockholm, Sweden, 2019. Available online: https://eatforum.org/ content/uploads/2019/11/Seafood_Scoping_Report_EAT-Lancet.pdf (accessed on 29 June 2021).

3. Abolofia, J.; Asche, F.; Wilen, J.E. The cost of lice: Quantifying the impacts of parasitic sea lice on farmed salmon. Mar. Resour. Econ. 2017, 32, 329-349. [CrossRef]

4. Olaussen, J.O. Environmental problems and regulation in the aquaculture industry. Insights from Norway. Mar. Policy 2018, 98, 158-163. [CrossRef]

5. Salin, K.R.; Arome Ataguba, G. Aquaculture and the Environment: Towards Sustainability. In Sustainable Aquaculture. Applied Environmental Science and Engineering for a Sustainable Future; Hai, F., Visvanathan, C., Boopathy, R., Eds.; Springer: Cham, Switzerland, 2018. [CrossRef] 
6. EEA (European Environment Agency). Food in a Green Light: A Systems Approach to Sustainable Food; European Environment Agency: Copenhagen, Denmark, 2017. Available online: https://www.eea.europa.eu/publications/food-in-a-green-light (accessed on 1 October 2021).

7. Pelletier, N.; Tyedmers, P.; Sonesson, U.; Scholz, A.; Ziegler, F.; Flysjo, A.; Kruse, S.; Cancino, B.; Silverman, H. Not all salmon are created equal: Life cycle assessment (LCA) of global salmon farming systems. Environ. Sci. Technol. 2009, 43, 8730-8736. [CrossRef]

8. Poore, J.; Nemecek, T. Reducing food's environmental impacts through producers and consumers. Science 2018, 360, 987-992. [CrossRef]

9. Chen, W.; Jafarzadeh, S.; Thakur, M.; Olafsdottir, G.; Mehta, S.; Bogason, S.; Holden, N.M. Environmental impacts of animal-based food supply chains with market characteristics. Sci. Total Environ. 2021, 782, 147077. [CrossRef] [PubMed]

10. Ziegler, F.; Jafarzadeh, S.; Skontorp Hognes, E.; Winther, U. Greenhouse gas emissions of Norwegian seafoods: From comprehensive to simplified assessment. J. Ind. Ecol. 2021, 1-12. [CrossRef]

11. Geels, F.W. From sectoral systems of innovation to socio-technical systems: Insights about dynamics and change from sociology and institutional theory. Res. Policy 2004, 33, 897-920. [CrossRef]

12. Loorbach, D.; Frantzeskaki, N.; Avelino, F. Sustainability transitions research: Transforming science and practice for societal change. Annu. Rev. Environ. Resour. 2017, 42, 599-626. [CrossRef]

13. El Bilali, $\mathrm{H}$. The Multi-Level perspective in research on sustainability transitions in agriculture and food systems: A systematic review. Agriculture 2019, 9, 74. [CrossRef]

14. Geels, F.W.; Kern, F.; Fuchs, G.; Hinderer, N.; Kungl, G.; Mylan, J.; Neukirch, M.; Wassermann, S. The enactment of socio-technical transition pathways: A reformulated typology and a comparative multi-level analysis of the German and UK low-carbon electricity transitions (1990-2014). Res. Policy 2016, 45, 896-913. [CrossRef]

15. Köhler, J.; Turnheim, B.; Hodson, M. Low carbon transitions pathways in mobility: Applying the MLP in a combined case study and simulation bridging analysis of passenger transport in the Netherlands. Technol. Forecast. Soc. Chang. 2020, 151, 119314. [CrossRef]

16. Bui, S.; Cardona, A.; Lamine, C.; Cerf, M. Sustainability transitions: Insights on processes of niche-regime interaction and regime reconfiguration in agri-food systems. J. Rural Stud. 2016, 48, 92-103. [CrossRef]

17. Bush, S.R.; Marchke, M.J. Making social sense of aquaculture transitions. Ecol. Soc. 2014, 19, 50. [CrossRef]

18. Kumar, G.; Engle, C.R. Technological advances that led to growth of shrimp, salmon, and tilapia farming. Rev. Fish. Sci. Aquac. 2016, 24, 136-152. [CrossRef]

19. Boyd, C.E.; D'Abramo, L.R.; Glencross, B.D.; Huyben, D.C.; Juarez, L.M.; Lockwood, G.S.; McNevin, A.A.; Tacon, A.G.J.; Teletchea, F.; Tomasso, J.R., Jr.; et al. Achieving sustainable aquaculture: Historical and current perspectives and future needs and challenges. J. World Aquac. Soc. 2020, 51, 578-633. [CrossRef]

20. Klinger, D.; Naylor, R. Searching for solutions in aquaculture: Charting a sustainable course. Annu. Rev. Environ. Resour. 2012, 37, 247-276. [CrossRef]

21. Mok, L.; Gaziulusoy, I. Designing for sustainability transitions of aquaculture in Finland. J. Clean. Prod. 2018, 194, 127-137. [CrossRef]

22. Hansen, L. The weak sustainability of the salmon feed transition in Norway-A bioeconomic case study. Front. Mar. Sci. 2019, 6, 764. [CrossRef]

23. Geels, F.W. Regime resistance against low-carbon transitions: Introducing politics and power into the multi-level perspective. Theory Cult. Soc. 2014, 31, 21-40. [CrossRef]

24. Gereffi, G.; Humphrey, J.; Sturgeon, T. The governance of global value chains. Rev. Int. Political Econ. 2005, 12, 78-104. [CrossRef]

25. Gereffi, G.; Lee, J.; Christian, M. US-based food and agricultural value chains and their relevance to healthy diets. J. Hunger Environ. Nutr. 2009, 4, 357-374. [CrossRef] [PubMed]

26. Carbone, A. Food supply chains: Coordination governance and other shaping force. Agric. Food Econ. 2017, 5, 1-23. [CrossRef]

27. Barling, D.; Gresham, D. (Eds.) Governance in European Food Value Chains; VALUMICS “Understanding Food Value Chains and Network Dynamics"; Funded by European Union's Horizon 2020 Research and Innovation Programme GA No 727243.; Deliverable: D5.1; University of Hertfordshire: Hatfield, UK, 2020; 237p. [CrossRef]

28. Iversen, A.; Asche, F.; Hermansen, Ø.; Nystøyl, R. Production cost and competitiveness in major salmon farming countries 2003-2018. Aquaculture 2020, 522, 735089. [CrossRef]

29. EUMOFA. The EU Fish Market, 2020th ed.; EUMOFA: Brussels, Belgium, 2020. Available online: https://www.eumofa.eu/ documents /20178/415635/EN_The+EU+fish+market_2020.pdf (accessed on 1 October 2021).

30. Bjarnason, A.; Magnusdottir, S.K. The salmon sea fish farming industry in Iceland: A review. Fish. Aquac. J. 2019, 10, 272. [CrossRef]

31. Geels, F.W.; Schot, J. Typology of sociotechnical transition pathways. Res. Policy 2007, 36, 399-417. [CrossRef]

32. Gereffi, G.; Lee, J. Economic and social upgrading in Global Value Chains and industrial clusters: Why governance matters. J. Bus. Ethics 2016, 133, 25-38. [CrossRef]

33. Geels, F.W. The multi-level perspective on sustainability transitions: Responses to seven criticisms. Environ. Innov. Soc. Transit. 2011, 1, 24-40. [CrossRef] 
34. Geels, F.W. Technological transitions as evolutionary reconfiguration processes: A multi-level perspective and a case-study. Res. Policy 2002, 31, 1257-1274. [CrossRef]

35. WHO (World Health Organization). Coronavirus Disease (COVID-19) Pandemic. 2021. Available online: https://www.who.int/ emergencies/diseases/novel-coronavirus-2019 (accessed on 18 August 2021).

36. Naylor, R.L.; Hardy, R.W.; Buschmann, A.H.; Bush, S.R.; Cao, L.; Klinger, D.H.; Little, D.C.; Lubchenco, J.; Shumway, S.E.; Troell, M. A 20-year retrospective review of global aquaculture. Nature 2021, 591, 551-563. [CrossRef]

37. FAO (Food and Agricultural Organization). Sustainable Food Systems: Concept and Framework; Food and Agricultural Organization: Rome, Italy, 2018. Available online: http:/ / www.fao.org/3/ca2079en/CA2079EN.pdf (accessed on 1 October 2021).

38. Hersoug, B.; Mikkelsen, E.; Karlsen, K.M. “Great expectations”-Allocating licenses with special requirements in Norwegian salmon farming. Mar. Policy 2019, 100, 152-162. [CrossRef]

39. Chávez, C.; Dresdner, J.; Figueroa, Y.; Quiroga, M. Main issues and challenges for sustainable development of salmon farming in Chile: A socio-economic perspective. Rev. Aquac. 2019, 11, 403-421. [CrossRef]

40. Geels, F.W. Socio-technical transitions to sustainability: A review of criticisms and elaborations of the Multi-Level Perspective. Curr. Opin. Environ. Sustain. 2019, 39, 187-201. [CrossRef]

41. Geels, F.W.; Schot, J. The dynamics of transitions: A socio-technical perspective. In Transitions to Sustainable Development: New Directions in the Study of Long-Term Transformative Change; Routledge Studies in Sustainability, Transitions; Grin, J., Rotmans, J., Schot, J., Eds.; Routledge: New York, NY, USA, 2010; pp. 11-101, ISBN 0-203-85659-7.

42. Klitkou, A.; Bolwig, S.; Hansen, T.; Wessberg, N. The role of lock-in mechanisms in transition processes: The case of energy for road transport. Environ. Innov. Soc. Transit. 2015, 16, 22-37. [CrossRef]

43. Olafsdottir, G.; Mehta, S.; Richardsen, R.; Cook, D.; Gudbrandsdottir, I.Y.; Thakur, M.; Lane, A.; Bogason, S.G. Governance of the farmed salmon Value Chain from Norway to the EU. Aquac. Eur. 2019, 44, 5-19. [CrossRef]

44. Svanidze, M.; Čechura, L.; Đurić, I.; Jaghdani, T.J.; Olafsdottir, G.; Thakur, M.; Samoggia, A.; Esposito, G.; Del Prete, M. Assessment of Price Formation and Market Power along the Food Chains; The VALUMICS Project Funded by EU Horizon 2020 G.A. No 727243; Deliverable: D5.5; Leibniz Institute of Agricultural Development in Transition Economies (IAMO): Halle, Germany, 2020; 114p. [CrossRef]

45. Jaghdani, T.J.; Čechura, L.; Ólafsdóttir, G.; Thakur, M. Market power in Norwegian Salmon Industry. In Proceedings of the 60th Annual Meeting of the Gesellschaft für Wirtschafts- und Sozialwissenschaften des Landbaues e.V. (Society for Economic and Social Sciences of Agriculture) (GEWISOLA), Halle, Germany, 23-25 September 2020. [CrossRef]

46. Olafsdottir, G.; Mehta, S.; Richardsen, R.; Cook, D.; Gudbrandsdottir, I.Y.; Thakur, M.; Lane, A.; Bogason, S.G. Governance of the farmed salmon value chain from Norway. In Governance in European Food Value Chains; VALUMICS “Understanding Food Value Chains and Network, Dynamics"; Funded by European Union's Horizon 2020 Research and Innovation Programme GA No, 727243; Deliverable:, D5.1; Barling, D., Gresham, J., Eds.; University of Hertfordshire: Hatfield, UK, 2019 ; Chapter 7; p. 237. [CrossRef]

47. Grin, J. Understanding transitions from a governance perspective. In Transitions to Sustainable Development: New Directions in the Study of Long-Term Transformative Change; Routledge Studies in Sustainability, Transitions; Grin, J., Rotmans, J., Schot, J., Eds.; Routledge: New York, NY, USA, 2010; pp. 242-358, ISBN 0-203-85659-7.

48. Directive (EU) 2016/680 of the European Union and of the Council of 27 April 2016, on the Protection of Natural Persons with Regard to the Processing of Personal Data. Available online: https://eur-lex.europa.eu/eli/reg/2016/679/oj (accessed on 23 August 2021).

49. Daniels, N.; Gillen, P.; Casson, K.; Wilson, I. STEER: Factors to consider when designing online focus groups using audiovisual technology in health research. Int. J. Qual. Methods 2019, 18, 1-11. [CrossRef]

50. Hennink, N.M. Focus Group Discussions; Kindle Edition; Oxford University Press: New York, NY, USA, 2014.

51. Krueger, R.A.; Casey, M.A. Focus Groups: A Practical Guide for Applied Research, 5th ed.; Sage: Thousand Oaks, CA, USA, 2015.

52. Lambert, S.D.; Loiselle, C.G. Combining individual interviews and focus groups to enhance data richness. J. Adv. Nurs. 2008, 62, 228-237. [CrossRef]

53. Merriam, S.B.; Tisdell, E.J. Qualitative Research: A Guide to Design and Implementation; Kindle Edition; John Wiley \& Sons: Hoboken, NJ, USA, 2016.

54. Corbin, J.M.; Strauss, A.C. Basics of Qualitative Research: Techniques and Procedures for Developing Grounded Theory, 4th ed.; Kindle Edition; SAGE Publications: Los Angeles, CA, USA, 2015.

55. Abrams, K.M.; Wang, Z.; Song, Y.J.; Galindo-Gonzalez, S. Data richness trade-offs between face-to-face, online audiovisual, and online text-only focus groups. Soc. Sci. Comput. Rev. 2015, 33, 80-96. [CrossRef]

56. Stewart, D.W.; Shamdasani, P. Online focus groups. J. Advert. 2017, 46, 48-60. [CrossRef]

57. Young, N.; Brattland, C.; Digiovanni, C.; Hersoug, B.; Johnsen, J.P.; Karlsen, K.M.; Kvalvik, I.; Olofsson, E.; Simonsen, K.; Solås, A.-M.; et al. Limitations to growth: Social-ecological challenges to aquaculture development in five wealthy nations. Mar. Policy 2019, 104, 216-224. [CrossRef]

58. Vince, J.; Haward, M. Hybrid governance of aquaculture: Opportunities and challenges. J. Environ. Manag. 2017, 201, 138-144. [CrossRef] [PubMed]

59. Government of Norway. A Sea of Opportunities: Aquaculture Strategy. 2021; (In Norwegian). Available online: https: / www. regjeringen.no/no/dokumenter/havbruksstrategien-et-hav-av-muligheter/id2864482/?ch=1 (accessed on 27 August 2021). 
60. COM (European Commission). Strategic Guidelines for a More Sustainable and Competitive EU Aquaculture for the Period 2021 to 2030; COM/2021/236 Final; European Commission: Brussels, Belgium, 2021. Available online: https://eur-lex.europa.eu/legalcontent/EN/TXT/?uri=COM:2021:236:FIN (accessed on 1 October 2021).

61. FAO. The State of World Fisheries and Aquaculture 2020; Sustainability in Action; FAO: Rome, Italy, 2020. [CrossRef]

62. World Bank. Fish to 2030: Prospects for Fisheries and Aquaculture; World Bank Report Number 83177-GLB; The World Bank: Washington, DC, USA, 2013. Available online: https://documents1.worldbank.org/curated/en/458631468152376668/pdf/8317 70WP0P11260ES003000Fish0to02030.pdf (accessed on 1 October 2021).

63. Willett, W.; Rockström, J.; Loken, B.; Springmann, M.; Lang, T.; Vermeulen, S.; Garnett, T.; Tilman, D.; DeClerck, F.; Wood, A.; et al. Food in the Anthropocene: The EAT-Lancet Commission on healthy diets from sustainable food systems. Lancet 2019, 393, 447-492. [CrossRef]

64. Ahmed, N.; Thompson, S.; Glaser, M. Global aquaculture productivity, environmental sustainability, and climate change adaptability. Environ. Manag. 2019, 63, 159-172. [CrossRef]

65. Naylor, R.L.; Goldburg, R.J.; Primavera, J.H.; Kautsky, N.; Beveridge, M.C.M.; Clay, J.; Folke, C.; Lubchenco, J.; Mooney, H.; Troell, M. Effect of aquaculture on world fish supplies. Nature 2000, 405, 1017-1024. [CrossRef]

66. Naylor, R.; Hindar, K.; Fleming, I.A.; Goldburg, R.; Williams, S.; Volpe, J.; Whoriskey, F.; Eagle, J.; Kelso, D.; Mangel, M. Fugitive salmon: Assessing the risks of escaped fish from net-pen aquaculture. BioScience 2005, 55, 427-437. [CrossRef]

67. Lekang, O.I.; Salas-Bringas, C.; Bostock, J.C. Challenges and emerging technical solutions in on-growing salmon farming. Aquac. Int. 2016, 24, 757-766. [CrossRef]

68. Glover, K.A.; Bos, J.B.; Urdal, K.; Madhun, A.S.; Sørvik, A.G.E.; Unneland, L.; Seliussen, B.B.; Skaala, Ø.; Skilbrei, O.T.; Tang, Y.; et al. Genetic screening of farmed Atlantic salmon escapees demonstrates that triploid fish display reduced migration to freshwater. Biol. Invasions 2016, 18, 1287-1294. [CrossRef]

69. Regueiro, L.; Newton, R.; Soula, M.; Méndez, D.; Kok, B.; Little, D.C.; Pastres, R.; Johansen, J.; Ferreira, M. Opportunities and limitations for the introduction of circular economy principles in EU aquaculture based on the regulatory framework. J. Ind. Ecol. 2021. [CrossRef]

70. Yue, K.; Shen, Y. An overview of disruptive technologies for aquaculture. Aquac. Fish. 2021, in press. [CrossRef]

71. Antonucci, F.; Costa, C. Precision aquaculture: A short review on engineering innovations. Aquac. Int. 2020, 28, 41-57. [CrossRef]

72. PwC. Sjømatbarometeret 2019; PwC: London, UK, 2019. Available online: https://www.pwc.no/no/publikasjoner/ Sjomatbarometer_WEB_V02.pdf (accessed on 27 August 2021).

73. Ayer, N.; Tyedmers, P. Assessing alternative aquaculture technologies: Life cycle assessment of salmonid culture systems in Canada. J. Clean. Prod. 2009, 17, 362-373. [CrossRef]

74. Ahmed, N.; Thompson, S.; Turchini, G.M. Organic aquaculture productivity, environmental sustainability, and food security: Insights from organic agriculture. Food Secur. 2020, 12, 1253-1267. [CrossRef]

75. Van Walraven, N.; Fjørtoft, H.B.; Stene, A. Less is more: Negative relationship between biomass density and sea lice infestation in marine salmon farming. Aquaculture 2021, 539, 736602. [CrossRef]

76. Pelletier, N.; Tyedmers, P. Feeding farmed salmon: Is organic better? Aquaculture 2007, 272, 399-416. [CrossRef]

77. Bjørndal, T.; Tusvik, A. Economic analysis of land based farming of salmon. Aquac. Econ. Manag. 2019, 23, 449-475. [CrossRef]

78. Lafont, M.; Dupont, S.; Cousin, P.; Vallauri, A.; Dupont, C. Back to the future: IoT to improve aquaculture: Real-time monitoring and algorithmic prediction of water parameters for aquaculture needs. In Proceedings of the 2019 Global IoT Summit (GIoTS), Aarhus, Denmark, 17-21 June 2019; IEEE: Piscataway, NJ, USA, 2019; pp. 1-6.

79. Dichter, A.; Henderson, K.; Riedel, R.; Riefer, D. How Airlines Can Chart a Path to Zero-Carbon Flying; McKinsey \& Company: Chicago, IL, USA, 2020. Available online: https://www.mckinsey.com/industries/travel-logistics-and-infrastructure/ourinsights / how-airlines-can-chart-a-path-to-zero-carbon-flying (accessed on 1 October 2021).

80. Gössling, S. Risks, resilience, and pathways to sustainable aviation: A COVID-19 perspective. J. Air Transp. Manag. 2020, 89, 101933. [CrossRef]

81. KONTALI. The Salmon Farming Industry in Norway 2019; KONTALI: Kristiansund, Norway, 2019. Available online: www.kontali.no (accessed on 1 October 2021).

82. Thakur, M.; Johansen, U.; Jafarzadeh, S.; Cechura, L.; Rumankova, L.; Kroupova, Z.Z.; Loveluck, W.; Mehta, S.; Aditjandra, P.; Gresham, J.; et al. Report on Information and Material Flow Analysis for the Selected Case Studies; The VALUMICS Project Funded by EU Horizon 2020 G.A. No 727243; Deliverable: D4.3; SINTEF Ocean: Trondheim, Norway, 2020; 70p. [CrossRef]

83. EY (Ernst \& Young AS). The Norwegian Aquaculture Analysis: An Overview; Ernst \& Young AS: London, UK, 2019. Available online: https:/ / assets.ey.com/content/dam/ey-sites/ey-com/no_no/topics/fiskeri-og-sj\%C3\%B8mat/norwegian-aquacultureanalysis_2019.pdf (accessed on 25 August 2021).

84. Kirchherr, J.; Reike, D.; Hekkert, M. Conceptualizing the circular economy: An analysis of 114 definitions. Resour. Conserv. Recycl. 2017, 127, 221-232. [CrossRef]

85. Korhonen, J.; Honkasalo, A.; Seppälä, J. Circular economy: The concept and its limitations. Ecol. Econ. 2018, 143, 37-46. [CrossRef]

86. Parker, R. Implications of high animal by-product feed inputs in life cycle assessments of farmed Atlantic salmon. Int. J. Life Cycle Assess. 2018, 23, 982-994. [CrossRef]

87. Sissener, N.H. Are we what we eat? Changes to the feed fatty acid composition of farmed salmon and its effects through the food chain. J. Exp. Biol. 2018, 221 (Suppl. 1), jeb161521. [CrossRef] 
88. Fisheries and Ocean Canada. Open-Net Pen Transition Plan in British Columbia: Initial Engagement Process; Fisheries and Ocean Canada: Ottawa, ON, Canada, 2021. Available online: https://waves-vagues.dfo-mpo.gc.ca/Library/40983778.pdf (accessed on 1 October 2021).

89. Christiansen, E.A.N.; Jakobsen, S.-E. Diversity in narratives to green the Norwegian salmon farming industry. Mar. Policy 2017, 75, 156-164. [CrossRef]

90. Osmundsen, T.C.; Almklov, P.; Tveterås, R. Fish farmers and regulators coping with the wickedness of aquaculture. Aquac. Econ. Manag. 2017, 21, 163-183. [CrossRef]

91. Gudbrandsdottir, I.Y.; Olafsdottir, G.; Oddsson, G.V.; Stefansson, H.; Bogason, S.G. Operationalization of interorganizational fairness in food systems: From a social construct to quantitative indicators. Agriculture 2021, 11, 36. [CrossRef]

92. Vince, J.; Haward, M. Hybrid governance in aquaculture: Certification schemes and third party accreditation. Aquaculture 2019, 507, 322-328. [CrossRef]

93. Tiller, R.G.; De Kok, J.-L.; Vermeiren, K.; Thorvaldsen, T. Accountability as a governance paradox in the Norwegian salmon aquaculture industry. Front. Mar. Sci. 2017, 4, 71. [CrossRef]

94. Bush, S.R.; Belton, B.; Hall, D.; Vandergeest, P.; Murray, F.J.; Ponte, S.; Oosterveer, P.; Islam, M.S.; Mol, A.P.J.; Hatanaka, M.; et al. Certify sustainable aquaculture? Science 2013, 341, 1067-1068. [CrossRef]

95. Saviolidis, N.M.; Davíðsdóttir, B.; Ilmola, L.; Stepanova, A.; Valman, M.; Rovenskaya, E. Realising blue growth in the fishing industry in Iceland and Norway: Industry perceptions on drivers and barriers to blue growth investments and policy implications. Mar. Policy 2020, 117, 103967. [CrossRef]

96. Bush, S.R. Understanding the potential of eco-certification in salmon and shrimp aquaculture value chains. Aquaculture 2018, 493, 376-383. [CrossRef]

97. Jonell, M.; Phillips, M.; Rönnbäck, P.; Troell, M. Eco-certification of farmed seafood: Will it make a difference? AMBIO 2013, 42, 659-674. [CrossRef]

98. Hersoug, B. The greening of Norwegian salmon production. Marit. Stud. 2015, 14, 16. [CrossRef]

99. Tlusty, M.F.; Tyedmers, P.; Bailey, M.; Ziegler, F.; Henriksson, P.J.; Béné, C.; Bush, S.; Newton, R.; Asche, F.; Little, D.C.; et al. Reframing the sustainable seafood narrative. Glob. Environ. Chang. 2019, 59, 101991. [CrossRef]

100. Saviolidis, N.M.; Olafsdottir, G.; Nicolau, M.; Samoggia, A.; Huber, E.; Brimont, L.; Gorton, M.; von Berlepsch, D.; Sigurdardottir H.; Del Prete, M.; et al. Stakeholder perceptions of policy tools in support of sustainable food consumption in Europe: Policy implications. Sustainability 2020, 12, 7161. [CrossRef]

101. Cadillo-Benalcazar, J.J.; Giampietro, M.; Bukkens, S.G.F.; Strand, R. Multi-scale integrated evaluation of the sustainability of large-scale use of alternative feeds in salmon aquaculture. J. Clean. Prod. 2020, 248, 119210. [CrossRef]

102. Springmann, M.; Clark, M.; Mason-D’Croz, D.; Wiebe, K.D.; Bodirsky, B.L.; Lassaletta, L.; De Vries, W.; Vermeulen, S.J.; Herrero, M.; Carlson, K.M.; et al. Options for keeping the food system within environmental limits. Nature 2018, 562, 519-525. [CrossRef]

103. Nordic Council of Ministers Solutions Menu_A Nordic Guide to Sustainable Food Policy. 2018. Available online: https://norden diva-portal.org/smash/get/diva2:1214792/FULLTEXT01.pdf (accessed on 23 February 2020).

104. COM (European Commission). Farm to Fork Strategy for a Fair, Healthy and Environmentally-Friendly Food System. 2020. Available online: https:/ / ec.europa.eu/food/farm2fork_en (accessed on 1 October 2021).

105. Little, D.C.; Young, J.A.; Zhang, W.; Newton, R.W.; Al Mamun, A.; Murray, F.J. Sustainable intensification of aquaculture value chains between Asia and Europe: A framework for understanding impacts and challenges. Aquaculture 2018, 493, 338-354. [CrossRef]

106. FAO (Food and Agricultural Organization). Achieving Blue Growth: Building Vibrant Fisheries and Aquaculture Communities; Food and Agricultural Organization: Rome, Italy, 2018. Available online: http:/ / www.fao.org/3/CA0268EN/ca0268en.pdf (accessed on 1 October 2021).

107. Osmundsen, T.C.; Olsen, M.S. The imperishable controversy over aquaculture. Mar. Policy 2017, 76, 136-142. [CrossRef] 